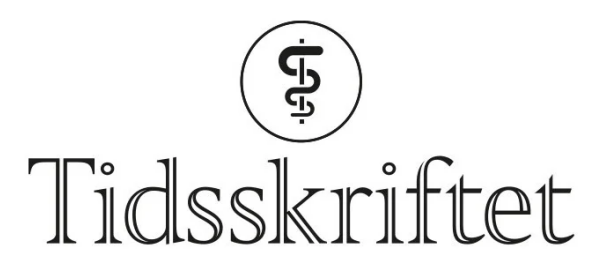

DEN NORSKE LEGEFORENING

\title{
Om hjernens arbeidsmåte
}

\author{
ANMELDELSER
}

PER BRODAL

Institutt for medisinske basalfag

Universitetet i Oslo

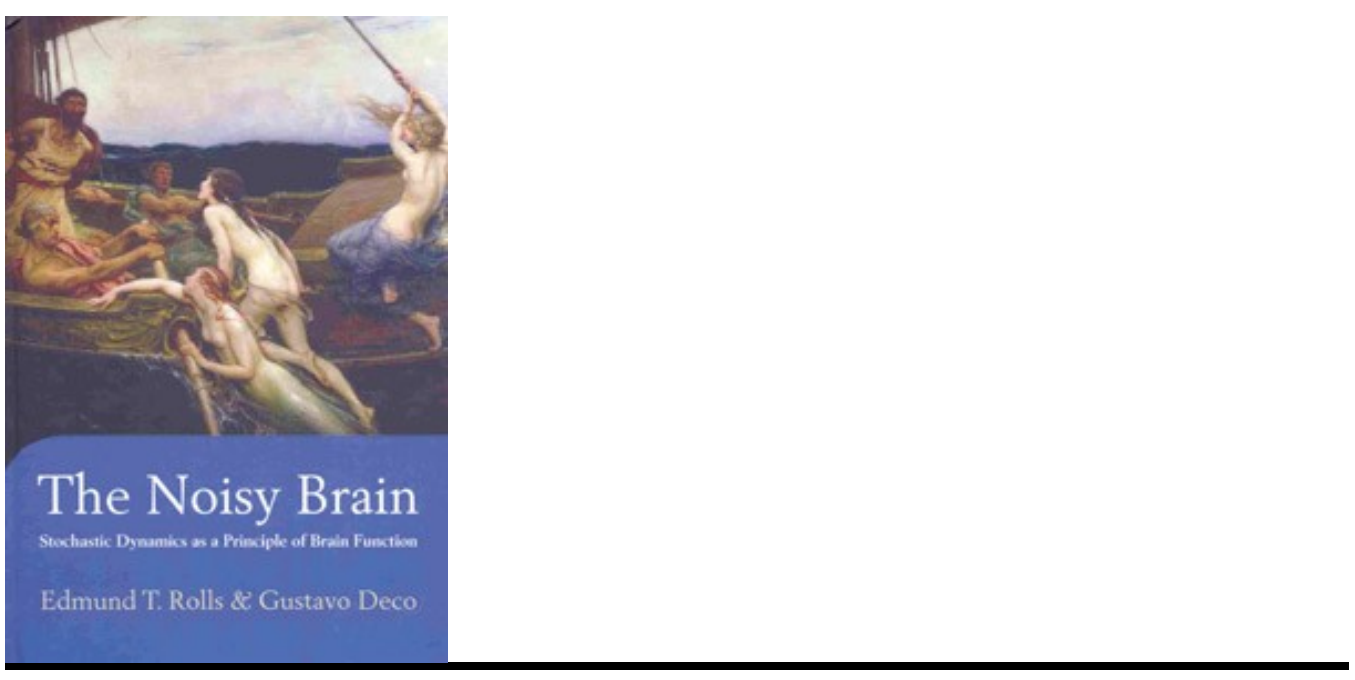

Rolls, ET

Deco, G.

The noisy brain

Stochastic dynamics as a principle of brain function. $316 \mathrm{~s}$, tab, ill. Oxford: Oxford University Press, 2010. Pris GBP 38

ISBN 978-0-19-958786-5

Forfatterne fremhever innledningsvis at for å forstå hvordan hjernen arbeider, må man kombinere mange ulike tilnærminger, fra nevrofysiologi på enkeltcellenivå til databaserte modelleringer (neural computation). Det gjelder ikke minst hvis ambisjonen er å forstå komplekse mentale funksjoner. Hvilke nevrale prosesser ligger f.eks. til grunn når vi fatter en beslutning? Hvordan de informasjonsbehandlende enhetene i hjernen virker sammen i nevrale nettverk er forfatternes hovedanliggende, men underveis trekker de inn kunnskap fra de fleste feltene innen nevrovitenskap og fra psykofysikk, psykologi og psykiatri. 
Tittelen henspiller på at det skapes støy i hjernen ved at enkeltnevroner danner aksjonspotensialer med et relativt tilfeldig mønster. Forfatterne redegjør, med støtte i sin egen og andres forskning, for hvordan en slik støy er en helt grunnleggende egenskap ved kortikale nettverk. Nevronenes oppførsel er stokastisk - deres oppførsel kan analyseres statistisk, men lar seg ikke forutsi presist. Det medfører en sannsynlighetsbasert atferd som kan være en fordel ved f.eks. beslutningstaking, og som også kan bidra til å hindre at systemer «låser» seg. De diskuterer også mange andre fordeler for hjernens informasjonsbehandling med en viss støy i de kortikale nettverkene.

Boken består av åtte kapitler med tallrike korte underavsnitt. I det første kapitlet får man en grunnleggende innføring i nevroners og hjernebarkens bygning og fysiologiske egenskaper (men på et forholdsvis høyt nivå). I det andre kapitlet beskriver man en databasert tilnærming til analyse av hjernefunksjon, hvor nevroners stokastiske signalegenskaper står i sentrum. I de følgende kapitlene anvender man denne tilnærmingen på en rekke sentrale funksjoner, som korttidshukommelse, oppmerksomhet, beslutningsprosesser, persepsjon, kreativitet, kognitiv aldring og drømmer. I tillegg drøfter forfatterne mulig relevans for symptomer ved schizofreni og enkelte andre tilstander.

Målgruppen er i første rekke lesere med solide forkunnskaper om nervesystemets struktur og fysiologi. For fullt utbytte kreves det i tillegg betydelig innsikt i matematikk og teoretisk fysikk (noe denne anmelderen ikke har). Men selv uten forutsetninger for å følge forfatterne på alle områder kan man få utbytte av deler av boken, hvor man analyserer grunnleggende mentale funksjoner og forstyrrelser av hjernefunksjonen.

Publisert: 9. september 2010. Tidsskr Nor Legeforen. DOI: 10.4045/tidsskr.10.0661

(C) Tidsskrift for Den norske legeforening 2023. Lastet ned fra tidsskriftet.no 26. april 2023. 